\section{NIH budget prospect bright despite political stalemate}

[WASHINGTON] Divided Republicans in the US House of Representatives last week put off until September further efforts to craft a bill to fund the National Institutes of Health (NIH) in fiscal year 2000, which starts on 1 October. They had been forced to concede that broader budget politics have thrown up obstacles that are currently insurmountable.

But the delay does not necessarily portend ill for the biomedical agency. As efforts to agree on a broad funding bill to include the NIH were failing last week, Congressman John Porter (Republican, Illinois), chairman of the labour, health and human services and education subcommittee of the House Appropriations Committee, drafted his own bill containing an 8.5 per cent boost for the $\mathrm{NIH}$, from $\$ 15.61$ billion to $\$ 16.95$ billion.

The bill never made it to the subcommittee hearing room. But it revealed what is likely to be the minimum increase that lawmakers will enact for the NIH, despite extraordinary limits on government spending being faced by the Congress.

In recent years, Congress has not let the figure for the agency fall below that suggested by Porter, an ardent advocate of biomedical research. Last year, he proposed a 9.1 per cent boost. House and Senate negotiators increased that to 14.6 per cent, resulting in a $\$ 2$ billion increase for the NIH.

Porter told Nature last week that he is hoping for a repeat performance. The 8.5 per cent increase "provides a floor", he said. His ultimate goal is a 15 per cent increase for the $\mathrm{NIH}$, and eventually a doubling over five years - a target supported by the research community and its allies in Congress.

"You have seen powerful evidence that congressional support may be turned into a good increase for NIH," says Mike Stephens, a lobbyist for the Federation of American Societies for Experimental Biology. He adds that the research community should be "buoyed" by Porter's figure.

But Porter cautioned biomedical scientists against assuming that the 15 per cent increase will be achieved. "What you do individually to impact your member of Congress, your senators and the White House is what will make the difference."

Doubling funding over five years would require a 15 per cent boost each year. Such an increase between 1999 and 2000 would require Congress to find an extra $\$ 2.34$ billion for the agency this summer.

Porter's Senate counterpart, Arlen Specter (Republican, Pennsylvania), says he is committed to at least a $\$ 2$ billion increase for the NIH. But Porter and Specter face formidable budgetary constraints. These make

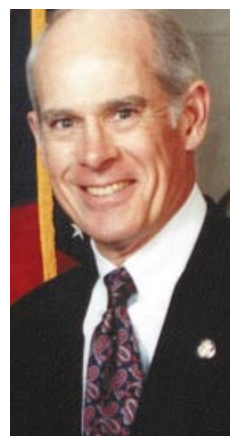

the agency's fiscal fate uncertain, despite bipartisan support for biomedical research in the House and Senate.

A 1997 budget law imposed caps on nonmandatory government spending, including money for science agencies. So Porter's subcommittee has been allotted Porter: suggesting $\$ 12$ billion less than last rise of 8.5 per cent. year to fund the nonmandatory programmes under its jurisdiction, while Specter's subcommittee faces an $\$ 8$ billion shortfall.

Unless Republican congressional leaders agree to break the budget caps, jettisoning the fiscal discipline that they imposed two years ago, it will be virtually impossible to fund such a substantial increase for the NIH. Porter is among Republicans calling for such a move because the government is operating in a surplus for the first time in 30 years.

More significantly, Senator Ted Stevens (Republican, Alaska), chairman of the Senate Appropriations Committee, has indicated his willingness to break the caps.

So many factors remain in play that, until September, when the subcommittees plan to finalize the NIH bill, the rise remains uncertain. Porter says he has been given "strong assurances" by House Republican leaders that they will produce the $\$ 12$ billion needed for his bill by September. But they have a razor-thin majority and must juggle a daunting array of considerations, including opposition to breaking the budget caps.

The NIH's prospects remain relatively good, but those of the National Science Foundation (NSF), the space agency NASA and the Environmental Protection Agency are less certain. Their funding depends on a bill that was scheduled to be finalized by the relevant House appropriations subcommittee last Monday (26 July).

The subcommittee is working with a budget allocation $\$ 7$ billion below last year's level for non-mandatory programmes. Republicans are trying to use 'emergency' spending and budgetary gimmicks to make up the shortfall while technically remaining within the budget caps.

But Congress is unlikely to match the 9 per cent increase that the NSF received last year. The problem for the NSF is that "everybody likes it but very few love it," says Howard Silver, who chairs the advocacy group the Coalition for National Science Funding.

MeredithWadman

\section{Michigan to use tobacco money to fund life sciences}

[WASHINGTON] The US state of Michigan is to fund a $\$ 50$ million-a-year research programme in basic life sciences with money that it will receive from tobacco companies under last year's settlement between the industry and state governments.

The state government hopes that the programme will help to create the critical mass of research needed to nurture a biotechnology industry. Additional impetus will come from major research institutes being built by the University of Michigan and the VanAndel Institute, a private foundation.

Michigan is the first state to dedicate such substantial resources to biomedical research. Scientists hope the idea will be taken up by other states with healthy budget surpluses that are set to receive substantial revenues from tobacco companies.

Governor John Engler said the programme "promises to make Michigan a world-class biotechnology powerhouse". The programme is intended to build on the strengths of the University of Michigan, Wayne State University, Michigan State University and the VanAndel Institute.

Under legislation that was signed by Engler last week, half the money will be directed at collaborations involving at least two institutions, 40 per cent will go to standard investigator grants for basic life science, and the rest will be used help to commercialize discoveries.

The use of tobacco settlement money for biomedical research has been suggested in Washington over the past two years, but Michigan is the first state to put it into practice (see Nature 391, 424; 1998).

"The symbolism of using tobacco money for research is very important," said Frank Press, former president of the National Academy of Sciences, speaking at a meeting in Washington at which Engler announced the initiative.

A 14-strong advisory panel, to be appointed by the governor, will draw up details of the programme, which will be administered by Michigan's Economic Development Commission. The first $\$ 50$ million will be distributed during the next fiscal year, which starts in October. The law authorizes $\$ 50$ million to be spent on the programme each year for 20 years, but actual spending will be subject to annual review by the state government.

Michigan's economy has traditionally been heavily reliant on the motor industry. Although the recent boom in that sector has helped the state, Michigan's political leadership is looking to diversify its economic interests.
Colin Macilwain 